\title{
Rural and urban employment patterns in Brazil: a dynamic panel data approach
}

Padrões de emprego rural e urbano no Brasil: um ensaio de dados em painel dinâmico L'emploi rural et urbain au Brésil: une démarche de données dynamique

\section{Padrones de empleo rural y urbano en Brasil: un enfoque en datos del panel dinámico}

\author{
Evanio Mascarenhas Paulo ${ }^{1}$ \\ Francisco José Silva Tabosa²
}

Recebido em 16/12/2017; revisado e aprovado em 05/05/2018; aceito em 23/05/2018

DOI: http://dx.doi.org/10.20435/inter.v19i4.1791

\begin{abstract}
This study applies a quantitative approach in dynamic panel data to capture the determinants of employment quality in Brazil through the model of generalized minimum moments. The results show that the rural universe persists as a more precarious environment than urban areas, although the differences has decreased with time. In addition, the results of this study show that growth of labor income and the level of education of employees are important tools not only to expand the levels of job quality, but also as response to dilemmas of the surveyed labor markets.
\end{abstract}

Keywords: labor market; occupation quality; panel data; agricultural and non-agricultural employment.

Resumo: Este estudo aplica uma abordagem quantitativa de dados em painel dinâmico por meio sistema de mínimos momentos generalizados para captar os determinantes da qualidade do emprego no Brasil. Os resultados mostram que o universo rural persiste como um ambiente mais precário que as áreas urbanas, embora essas diferenças tenham diminuído com o tempo. Adicionalmente, os resultados desse estudo mostram que o crescimento da renda do trabalho e do nível de educação dos trabalhadores são fatores importantes para expandir o nível de qualidade do emprego e também como resposta aos dilemas dos mercados de trabalho pesquisados.

Palavras-chave: mercado de trabalho; qualidade das ocupações; emprego agrícola e não agrícola.

Résumé: Dans cette étude, une approche quantitative de données de panel est appliquée pour capturer les conditions de qualité de l'emploi à travers le modèle des moments minimum généralisés. Sur les résultats, l'univers rural persiste comme un environnement plus précaire par rapport aux zones urbaines, même si les différences ont diminué au fil du temps. On a fait valoir que le revenu des travailleurs et le niveau d'éducation sont importants pour l'expansion de la qualité de l'emploi, mais aussi une stratégie pour surmonter dilemmes des marchés analysés.

Mots-clés: marche du travail; qualite de l'occupation; panneau de donnees; emploi agricole et non agricole.

Resumen: En este estudio se aplica un cuantitativo enfoque en datos de panel para captar condicionantes de la calidad del empleo en Brasil, a través del modelo de mínimos momentos generalizados. Sobre los resultados, el universo rural persiste como un ambiente más precario cuando se compara con las zonas urbanas, aunque las diferencias hayan disminuido con el tiempo. La investigación mostró también que el crecimiento de los ingresos del trabajo y el nivel de escolaridad de los trabajadores son instrumentos importantes para la ampliación de los niveles de calidad del empleo, sino también estrategia de superación de dilemas de los mercados de trabajo analizados.

Palabras clave: mercado laboral; calidad de la ocupación; panel de datos; empleo agrícola y no agrícola.

\section{INTRODUCTION}

Authors, such as Balsadi (2007), Schneider (2005) e Da Silva (1998), have promoted efforts to undo the distinction between rural and urban areas. These authors argue that current human development needs have not been met by projects aimed to remove this disparity, as shown by Da Silva (1998), These authors use labor market elements to explain these needs, since the

\footnotetext{
${ }^{1}$ Pontifícia Universidade Católica do Rio Grande do Sul (PUC-RS), Porto Alegre, Rio Grande do Sul, Brasil.

${ }^{2}$ Universidade Federal do Ceará (UFC), Campus Pici, Fortaleza, Ceará, Brasil.
} 
labor market mirrors the transformation that occurs in the rural areas from the introduction of labor-saving technologies, which aim to reducing costs and increasing productivity.

Already for Schneider (2005), the behavior of the labor market, which is subject to the logic of production relations, is influenced by the movement of phenomena that affect the agricultural paradigm, translating into a continuous increase of labor productivity in agricultural activities because of the introduction of innovative technologies and modernization of agriculture.

In this regard, Da Silva (1998) states that, as a function of changes in productive units, two major types of transformation occur in the agricultural labor market. First, there is a new division of labor within family units, as some members of families are released for work in other activities, beyond the family production unit. Second, family members who are involved in agricultural work have reduced work time, in order to enable combining agricultural work for the family with other productive activities.

Da Silva (1998) goes further to say that difference between these two types of transformation is unit of analysis - the first relates to families and their members, while the second concerns the agricultural establishment, observing the time devoted to farming activities by people.

In the first case, individuals released by the modernization process remain in rural areas, but work in activities that are not necessarily agricultural, thereby expanding and consolidating this category of residents in rural areas. Therefore, if spatial migration from the countryside to the city has decreased, as observed in Alves e Paulo (2012, p. 51), then the transfer from the rural labor force to non-agricultural activities describes the sectoral migration of laborers, which has increased considerably, according to Paulo (2015). He still has identified that the migration of this type of worker to the non-agricultural labor market in many cases occurs under precarious conditions, because of the low qualifications of this worker type.

It is noted that the impacts the quality standards of their occupations decrease when compared to their work in agriculture, because the agricultural productive structure, before the modernization process, had even more precarious working conditions than non-agricultural sectors. Thus, even though the new occupations are precarious, they are still better than the previous ones.

This study aims to analyze the components of the quality of occupation of rural workers in Brazil, by considering recent aspects of production relations in rural areas and their implications for labor relations. In particular, this study discusses recent changes in the rural labor market, with special emphasis on the impacts caused by transformation in the rural areas. In addition, this study checks the quality level of rural occupations in Brazil based on a job quality index, in order to identify contributing factors to the quality of rural occupations using a panel data model.

\section{CONCEPTUAL AND METHODOLOGICAL ASPECTS}

\subsection{Dataset and construction of employment quality index}

The data used in the study are from National Research of the Brazilian Institute of Geography (IBGE), and statistics for the period that comprises the years 2002 to 2011 . This period was important for the analysis of the Brazilian labor market, especially rural employment, owing to the consolidation of changes in the world of work. The employment quality index (EQI) in this study is composed of the calculation of partial indexes for Brazilian states, as outlined in the following methodology. 
This research seeks to identify the conditions of the quality of occupations for four major population groups. The first comprises urban agricultural employees, consisting of employed, salaried people, both formal and informal, in ventures and agricultural groups domiciled in rural areas. The second group of workers comprises urban non-agricultural wage earners and non-agricultural enterprises domiciled in urban regions. The third group comprises employees engaged in agricultural activities and who live in rural areas. Finally, the fourth group comprises rural non-agricultural enterprise employees.

For Nascimento et al. (2007), the perception of job quality can vary in several aspects as macroeconomic environment, sector structure, among others. However, the intention in this research is to consider variables in the labor market relevant to the quality of employment, such as the absence of child labor, the regular weekly journey, register in officially registered, the contribution to social security institutes and yield.

In this way, the Employment Quality Index (EQI), in this study, is an adaptation of the employment quality index formulated initially by Balsadi (2007).

Table 1 - Methodology of constructing employment quality index

\begin{tabular}{|c|c|c|c|}
\hline \multicolumn{2}{|r|}{$\begin{array}{c}\text { Variable } \\
\text { (Percentage of population) }\end{array}$} & Partial Indicator & $\begin{array}{l}\text { Employment Quality } \\
\text { Index }\end{array}$ \\
\hline A & Over the age of 15 years & \multirow{4}{*}{$F O R=(0.1 A+0.2 B+0.4 C+0.3 D)$} & \multirow{6}{*}{ EQI } \\
\hline B & With weekly journey of up to 44 hours & & \\
\hline C & Officially registered & & \\
\hline $\mathrm{D}$ & Social security contributors & & \\
\hline $\mathrm{E}$ & $\begin{array}{l}\text { Average monthly income in main } \\
\text { work (standardized) }\end{array}$ & \multirow{2}{*}{$\begin{array}{c}\mathrm{INC}=0.6 \mathrm{E}+0.4 \mathrm{~F} \\
\text { Income (INC) }\end{array}$} & \\
\hline $\mathrm{F}$ & $\begin{array}{l}\text { With minimum remuneration above } \\
1 \mathrm{~S} . \mathrm{M} \text {. }\end{array}$ & & \\
\hline
\end{tabular}

Source: based on Balsadi and Da Silva (2008)

Second, following Nascimento et al. (2007), the EQI is used to from the weighted average of partial indicators. According to the authors, the weight of each partial indicator for composition of the EQI reflected the relative contributions. Of the indicators, only average monthly income had to be standardized to a range from 0 to 1 . These indicators are used to build two partial indexes from the weighted arithmetic averages of the original indicators. Soon, two segments are considered for the calculation of the index of employment: formality and income. Each of these partial indicators identifies elements about the presence or absence of formal work and income levels of workers. The weighted average of the partial indicators demonstrates that a general index, considering the necessary arbitrariness, can help in the analysis of the quality of employment, thereby contributing to a more detailed understanding of the conditions of work.

\subsection{Description of variables}

For the identification of occupations of the groups that this research aims to analyze, this study builds a conglomerate of variables that can synthesize the constraints of the standard qualities of labor relations. These variables are summarized in Table 2.

The first variable described $(Q E)$ refers to the job quality index ( $E Q I)$ whose construction is outlined in Subsection 2.1. The index gathers information about the level of formalization of 
employment contracts and the pattern of income of workers. Thus, it indicates how sophisticated the working relationships are. Then, it will be possible to check for possible differences between the recruitment of labor in rural areas in agriculture compared to contractual relations in urban areas and in activities of non-agricultural segments, so as to trace their determinants and contributions to employment quality.

The next variable described $\left(Q E_{t-1}\right)$ is the outdated $E Q l$, which is a feature of the econometric modeling type, selected in this research, to evaluate the properties of working relationships. It is expected that this variable is statistically significant in that the quality of employment in the previous period is the determinant of the quality of future employment. This hypothesis is due to the natural movement of the dynamics of the labor market, which tends to improve working relationships over time, being remote the return to a previous pattern and the presence and specific characteristics of labor laws that secure a contractual relationship to be pursued by the market and a retraction of those rights could result in a disregard for labor laws.

Table $\mathbf{2}$ - Survey variables and code and source of variables

\begin{tabular}{|c|c|c|}
\hline Variable & Variable Code & Source \\
\hline $\begin{array}{l}\text { Natural logarithm of the occupation quality index } \\
\text { (EQI) }\end{array}$ & QE & Authors' construction \\
\hline $\begin{array}{l}\text { Natural logarithm of the outdated occupation } \\
\text { quality index }\end{array}$ & $Q E_{t-1}$ & Endogenous variable \\
\hline $\begin{array}{l}\text { Natural logarithm of value added } \\
\text { Agriculture }\end{array}$ & VA1 & $\begin{array}{l}\text { Brazilian Institute of } \\
\text { Geography and Statistics }\end{array}$ \\
\hline $\begin{array}{l}\text { Natural logarithm of value added } \\
\text { non-agricultural }\end{array}$ & VA2 & $\begin{array}{l}\text { Brazilian Institute of } \\
\text { Geography and Statistics }\end{array}$ \\
\hline $\begin{array}{l}\text { Natural logarithm of the average yield of the main } \\
\text { work of urban farm workers }\end{array}$ & IN1 & $\begin{array}{l}\text { Brazilian Institute of } \\
\text { Geography and Statistics }\end{array}$ \\
\hline $\begin{array}{l}\text { Natural logarithm of the average yield of the main } \\
\text { work of urban non-agricultural workers }\end{array}$ & IN2 & $\begin{array}{l}\text { Brazilian Institute of } \\
\text { Geography and Statistics }\end{array}$ \\
\hline $\begin{array}{l}\text { Natural logarithm of the average yield of the main } \\
\text { work of rural non-agricultural workers }\end{array}$ & IN3 & $\begin{array}{l}\text { Brazilian Institute of } \\
\text { Geography and Statistics }\end{array}$ \\
\hline $\begin{array}{l}\text { Natural logarithm of the average yield of the main } \\
\text { work of rural agricultural workers }\end{array}$ & IN4 & $\begin{array}{l}\text { Brazilian Institute of } \\
\text { Geography and Statistics }\end{array}$ \\
\hline $\begin{array}{l}\text { Natural logarithm of the Gini concentration index } \\
\text { for income from work }\end{array}$ & IG & Authors' construction \\
\hline $\begin{array}{l}\text { Natural logarithm of the average level of schooling } \\
\text { of urban workers }\end{array}$ & ED1 & $\begin{array}{l}\text { Brazilian Institute of } \\
\text { Geography and Statistics }\end{array}$ \\
\hline $\begin{array}{l}\text { Natural logarithm of the average level of schooling } \\
\text { of rural workers }\end{array}$ & ED2 & $\begin{array}{l}\text { Brazilian Institute of } \\
\text { Geography and Statistics }\end{array}$ \\
\hline
\end{tabular}

Source: author's information.

Next, the variable AV1 represents the value added of agricultural activities of each State. One option for this variable is to allow an increase in the level of goods produced by all the agricultural activities of the States, which tends to raise the quality of employment. The logic involved is that agricultural growth induces an increase in the demand for labor by increasing 
the income level of workers and improving working conditions. Another option for this variable is that the level of agricultural activities is unrelated to the increase in the quality of the labor market. Thus, economic growth extends to new hires the same contractual relations already existing, and thus, there are no changes in the structure.

The variable AV2, which expresses the value added of non-agricultural activities, is expected to exert positive effects on the quality of occupations, to the extent that the increase of jobs, which in the case of non-agricultural activities, tends to have greater complexity and higher quality than agricultural occupations. Furthermore, just as in the previous case, the variable in question might not be related to increased quality of employment contracts, because this does not necessarily mean changes in contracting relationships.

In addition, search assesses cross-effects behavior, that is, the effects that economic growth in the non-agricultural activities has on the dynamics of the agricultural and rural employment and economic growth of agricultural activities have on the quality of non-farm employment and urban employment.

The group of variables "IN" expresses the average income level of the main work for each study group evaluated. Thus, the express level IN1 is the average income of urban agricultural workers; IN2 is the average yield of non-agricultural workers; IN3 is the average income of rural non-agricultural workers; and, finally, IN4 is the average income of rural farm workers.

It is expected that as the level of real wages increases, it may regress on additional real income gains, which improves the quality of occupations in very informal sectors, due to increased opportunity costs.

The variable " $I G$ " expresses the Gini index, which measures the level of concentration of income from work. Thus, this variable is evaluated as if it distributes the structure of labor income, that is, how focused the job market is in each State. The expected negative sign is justified by the perception that the increasing concentration of income standard tends to decrease the quality of the occupations. It is assumed that in the case of this insignificant coefficient, the quality of work is independent of the concentration of income in the labor market. Thus, the growth of income guarantees, by itself, the quality of growth occupations, even if this means changes in the structure of concentration.

Finally, the variable " $E D$ " expresses the average education level for those who reside in urban areas (ED1) and those who reside in rural areas (ED2). Considering that common sense assumes that the higher the level of education, the greater is work efficiency, and that the general quality of work increases if level of education increases.

\subsubsection{Method of generalized moments}

The nature of various economic relations is dynamic and complex, making purely static analysis, sometimes inadequate or inefficient, for understanding the needs of these relationships the work. An advantage of panel data is that they allow understanding the dynamics of adjustment. This dynamic relationship is characterized by the presence of a lagged dependent variable among the explanatory variables (BALTAGI, 2005). Thus, the following model is used:

$$
y_{i t}=\delta\left[y_{i t-1}\right]+B\left[x_{i t}^{\prime}\right]+u_{i t}
$$


The text assume still that $\mathrm{u}_{i t}$ follows a one-way error component model, where $u_{i t}-\left(u_{i}+v_{i t}\right)$ and $u_{i} \sim \| D\left(0, \theta_{u}\right)$ e $v_{i t} \sim \| D\left(0, \theta_{v}\right)$ are independent of each other and among themselves. "The dynamic panel data regression described in (1) and $u_{i t}$ is characterized by two sources of persistence over time. The autocorrelation is due to the presence of a lagged dependent variable among the regressors and individual effects characterizing the heterogeneity among the individuals" Baltagi (2005, p. 135). The attention that the described model produces are estimators skewed by conventional estimates. In this perspective now, the objective on analyzing recent econometric models that propose new procedures to estimate and test in the model.

Thus, this research proposes an approach conform Baltagi (2005). Therefore, this study employs the system generalized method of moments (system GMM), developed in the works of Arellano and Bond (1991; ), Arellano and Bover (1995), Bond, Hoeffler and Temple (2001) and Blundell and Bond (1998). In summary, this research uses panel data to estimate models specified, in the regression models the following four equations:

$$
\begin{aligned}
& \ln \left(Q_{A U}\right)=\beta_{0}+\beta_{1} \ln \left(Q E_{t-1}\right)+\beta_{2} \ln (V A 1)+\beta_{3} \ln (V A 2)+\beta_{4} \ln (I N 1)+\beta_{5} \ln (I G)+\beta_{6} \ln (E D 1)+V_{t}+\mu_{i t} \\
& \ln \left(Q E_{N U}\right)=\beta_{0}+\beta_{1} \ln \left(Q E_{t-1}\right)+\beta_{2} \ln (A V 1)+\beta_{3} \ln (A V 2)+\beta_{4} \ln (I N 2)+\beta_{5} \ln (I G)+\beta_{6} \ln (E D 1)+V_{t}+\mu_{i t} \\
& \ln \left(Q E_{N R}\right)=\beta_{0}+\beta_{1} \ln \left(Q E_{t-1}\right)+\beta_{2} \ln (A V 1)+\beta_{3} \ln (A V 2)+\beta_{4} \ln (I N 3)+\beta_{5} \ln (I G)+\beta_{6} \ln (E D 2)+V_{t}+\mu_{i t} \\
& \ln \left(Q_{E_{A R}}\right)=\beta_{0}+\beta_{1} \ln \left(Q E_{t-1}\right)+\beta_{2} \ln (A V 1)+\beta_{3} \ln (A V 2)+\beta_{4} \ln (I N 4)+\beta_{5} \ln (I G)+\beta_{6} \ln (E D 2)+V_{t}+\mu_{i t}
\end{aligned}
$$

where the dependent variable is the $Q E$ of each unit of the federation and their subscripts refer to agricultural employment $(A U)$, urban non-farm employment $(N U)$, rural non-agricultural $(N R)$, and rural agricultural $(A R)$, respectively; $Q E_{t-1}$ expresses the outdated $E Q I$, noting that in each case, this variable represents the lagged dependent variable for each group. The introduction of this variable is characteristic of this type of econometric modeling; AV1 represents the value added in the agricultural activities of each unit of the federation; AV2 expresses the value added in the non-agricultural activities of each unit of the federation; IN1 represents the average yield of the main agricultural activities in urban work in the reference week in the first equation; IN2 represents the average yield of the main work in urban non-agricultural activities in the reference week in the second equation; IN3 represents the average yield of the main work in rural non-agricultural activities in the reference week in the third equation; IN4 represents the average yield of main agricultural rural work in the reference week in the fourth equation; $I G$ expresses the level of concentration of the average yields for each state, measured by the Gini index; ED1 represents the average level of education of the urban workers of each subnational unit in the first two equations; ED2 represents the average level of education of rural workers at a subnational unit in the last two equations; $V_{i}$ is the observable effects of individuals; and $\mu_{i t}$ represents the random disturbances. The subscripts $i$ and $t$ refer to the $i$-th State in year $t$, respectively.

Ahn and Schmidt (1995), show that these models have the following hypothesis: $E\left[v_{i}\right]=E\left[\mu_{i t}\right]=E\left[v_{i} \mu_{i t}\right]=0$ for $i=1,2, \ldots, n$ and $t=1,2, \ldots, t$. Furthermore, it is assumed that the error is not temporally correlated, that is, $E\left|\mu_{i, t} \mu_{i, s}\right|=0$ for $i=1,2, \ldots, n \forall t \neq s$. In addition, there is $m$, the default hypothesis on the initial conditions $E\left|Q E_{t-1} \mu_{i t}\right|=0$ for $i=1,2, \ldots, n$ and $t=1,2$, 
..., $t$, these assumptions being valid for all the other equations of the models presented above.

The works presented in the literature, in particular that of Arellano and Bond (1991), highlight some problems in estimating these models by traditional techniques. The first, problem is due to the presence of the observable effects of individuals, $V_{t}$ along with the lagged dependent variable in period $Q E_{t-1}$ on the right side of the equation. In this case, omission of the individual fixed effects panel dynamic model makes the ordinary least squares estimator (MQO) skewed and inconsistent. However, the estimator within groups, which fixes for presence of fixed effects, generates an estimated $\beta_{i}$ skewed downward on panels with small temporal dimension. The second problem is due to the likely endogeneity of explanatory variables. In this case, the endogeneity in the right side of the equations must be treated to avoid possible bias generated by a concurrency problem.

Araújo (2009) states that a possible method of trying to overcome this problem would be to eliminate the presence of the fixed-effects model (equations presented above). Thus, a first attempt would be to estimate the models through ordinary least squares (MQO) with dummy variables for each state or through the method within groups, which generates the same estimates of the previous method, but with standard deviations of slightly smaller coefficients. The coefficient estimators for both methods are smaller than the MQO obtained. However, it could be shown that the bias in dynamic panel data continues to exist.

Nonetheless, according to Araújo (2009), another way to eliminate these problems would be to take the first difference of the above equations and treat them by the GMM. This method is usually called difference GMM and consists of the elimination of fixed effects through the first difference of the previous equations. Therefore, equation (1), for example, was transformed into equation (6) as follows:

$\Delta \ln \left(Q_{A U}\right)=\beta_{0}+\beta_{1} \Delta\left(\ln Q E_{t-1}\right)+\beta_{2} \Delta(\ln V A 1)+\beta_{3} \Delta(\ln V A 2)+\beta_{4} \Delta(\operatorname{IN} 1)+\beta_{5} \Delta(\ln \mid \mathrm{G})+\beta_{6} \Delta(\ln E D 1)+V_{t}+\mu_{i t}$

where for any variable, $Y_{i t}, \Delta \ln Y_{i t}=\ln Y_{i t}-\ln Y_{i t-1}$. Note that in the above equations, $\Delta \ln Q E_{t-1}$ is correlated with the error terms, $\Delta \ln \mu_{i t}$. Therefore, the ordinary least squares estimator (MQO) for their coefficients will be skewed and inconsistent. Therefore, it is necessary to use instrumental variables for $\triangle \operatorname{lnQE}_{\mathrm{t}-1}$ and in each model.

The assumptions adopted in the equations presented earlier in this section imply that the conditions of moments $E\left[\Delta \operatorname{lnQ} E_{t-1} \Delta \ln \mu_{i t}\right]=0$ for $t=3,4, \ldots, n$ and $s \geq 2$ are valid. Based on these moments, Arellano and Bond (1991) suggest hiring $\operatorname{lnQE}_{t-1}$ for $t=3,4, \ldots, n$ and $s \geq 2$ as instruments for the equation of first difference.

The other explanatory variables can be classified as: (a) strictly exogenous, if is not correlated with the error terms in the past, present and future; (b) weakly exogenous, if is correlated only with values passed the error term and (c) endogenous, if correlated with the error terms in the past, present and future. (ARAÚJO, 2009, p. 61).

In the second case, the lagged variable values in one or more periods are valid instruments in the estimation equation and in the latter case, values that are off by two or more periods are valid instruments in estimating this equation.

As Arellano and Bover (1995) and Blundell and Bond (1998) show, these instruments are weak when the dependent and explanatory variables feature strong persistence and/or the relative variance of fixed effects increases. This produces an estimator difference GMM that is not 
consistent and is skewed to panels with small T.

Therefore, Arellano and Bover (1995) and Blundell and Bond (1998) propose a system that combines the set of equations into difference equation (2), with the level equations, equation (1), to reduce this problem of bias. This system is called the system GMM. For the difference equations, the set of instruments is the same as described above. For regression in level, the appropriate instruments are lagged differences of their variables. For example, assume that the differences of the explanatory variables are not correlated with the individual fixed effects (for $t=3,4, \ldots, n) E\left[\Delta \operatorname{lnQ}_{t}, \mu_{i t}\right]=0$ for $i=1,2, \ldots, n$. Then, the explanatory variables in differences and $\triangle \operatorname{lnQE}_{t-1}$ if they are exogenous or weakly exogenous are valid instruments for the equations. The same is true if these variables are endogenous, but with the instruments being explanatory variables in a period, lagged differences and $\Delta \operatorname{lnQE}_{t-1}$ are considered in this study (ARAÚJO, 2009).

System GMM estimates the results from the method of standard error correction (WINDMEIJER, 2005) to prevent underestimating the true variance in a finite sample. The estimator used is proposed by Arellano and Bond (1991) in two steps. In the first step, it is assumed that the error terms are independent and homoscedastic in the states and over time. In the second stage, the residues obtained in the first step are used to build a consistent estimate of variance-covariance, relaxing the assumptions of independence and scapular. The second-stage estimator is asymptotically more efficient in relation to the first-stage estimator (ARAÚJO, 2009).

Finally, as a way to test the robustness and consistency of the model, Arellano and Bond (1991) suggest two types of tests. The Sargan test is used to verify the validity of the instruments. Failure to reject the null hypothesis indicates that the instruments are robust. Furthermore, since it is assumed that the it error is not autocorrelated, a first-order serial correlation test and a second-order correlation test are performed on the first-difference residues $\Delta \square_{\text {it }}$. It is expected that these errors will be correlated in the first order and not autocorrelated in the second order (ARAÚJO, 2009).

\section{EMPLOYMENT QUALITY INDEX: EMPIRICAL RESULTS}

This section presents and discusses the results of the econometric model presented in Subsection 2.2, relating the $E Q /$ for the four groups surveyed to some variables that synthesize the constraints of the structure of the labor market. Therefore, this section is organized by the interpretation of the following Tables 3-6 concerning estimates of the four proposed equations. The interpretation begins with data on urban and agricultural employment, followed by urban and non-agricultural employment, rural non-agricultural employment and finally agricultural rural employment.

Column $[A]$ of each of Tables 3-6 shows the results of the ordinary least squares estimates (MQO); column [B] presents the estimates of the fixed-effect panel method, which appears more efficient than the random-effects panel, according to the Hausman test on all four estimated models. Finally, column [C] presents estimates of the parameters by system GMM. As discussed in Subsection 2.2.1, this method results in an extension of the original estimator of Arellano and Bond (1991), proposed in Arellano and Bover (1995), and developed in Blundell and Bond (1998). 
Table 3 - Ordinary least squares estimates, fixed effects, and generalized least squares for the urban agricultural labor market

\begin{tabular}{|c|c|c|c|c|c|c|c|c|c|}
\hline \multirow[t]{2}{*}{ Variables } & \multicolumn{3}{|c|}{$\begin{array}{l}\text { Ordinary least squares } \\
{[\mathrm{A}]}\end{array}$} & \multicolumn{3}{|c|}{$\begin{array}{l}\text { Fixed-effects model } \\
{[\mathrm{B}]}\end{array}$} & \multicolumn{3}{|c|}{$\begin{array}{c}\text { Generalized least squares } \\
{[\mathrm{C}]}\end{array}$} \\
\hline & Coef. & Stat. (t) & p-value & Coef. & Stat. $(t)$ & p-value & Coef. & Stat. $(t)$ & $p$-value \\
\hline E. Q. $I_{t-1}$ & 0.322 & 5.050 & 0.000 & 0.183 & 2.820 & 0.011 & 0.309 & 16.870 & 0.000 \\
\hline Agri. value added & -0.008 & -0.590 & 0.556 & 0.001 & 0.010 & 0.989 & -0.074 & -3.140 & 0.005 \\
\hline Non-agri. value added & 0.012 & 1.180 & 0.239 & 0.080 & 0.550 & 0.590 & 0.141 & 5.570 & 0.000 \\
\hline Average income & 0.421 & 8.910 & 0.000 & 0.784 & 4.150 & 0.000 & 0.298 & 8.310 & 0.000 \\
\hline Gini index & -0.186 & -1.060 & 0.288 & -0.188 & -0.620 & 0.541 & -0.559 & -6.320 & 0.000 \\
\hline Schooling & 1.524 & 4.960 & 0.000 & -0.377 & -0.540 & 0.597 & 1.407 & 8.730 & 0.000 \\
\hline Constant & -6.699 & -8.360 & 0.000 & -5.566 & -5.510 & 0.000 & -6.858 & -23.950 & 0.000 \\
\hline \multirow{9}{*}{ Statistical tests } & \multicolumn{3}{|c|}{$F(6,182)=254.92$} & \multicolumn{3}{|c|}{$F(6,20)=150.06$} & \multicolumn{3}{|c|}{$F(6,20)=152.61$} \\
\hline & \multicolumn{3}{|c|}{ Prob $>F=0.000$} & \multirow{2}{*}{\multicolumn{3}{|c|}{ Prob $>F=0.000$}} & \multirow{2}{*}{\multicolumn{3}{|c|}{ Prob $>F=0.000$}} \\
\hline & \multicolumn{3}{|c|}{$R^{2}=0.9046$} & & & & & & \\
\hline & Number c & f comme & nts $=189$ & \multicolumn{3}{|c|}{ Number of comments $=189$} & \multicolumn{3}{|c|}{ Number of comments $=189$} \\
\hline & & & & \multicolumn{3}{|c|}{ Number of groups $=21$} & \multicolumn{3}{|c|}{ Number of groups $=21$} \\
\hline & & & & & & & \multirow{2}{*}{\multicolumn{3}{|c|}{$\begin{aligned} \text { Instruments }=19.4 \\
0.005\end{aligned}$}} \\
\hline & \multicolumn{6}{|c|}{ HO: the absence of first-order autocorrelation } & & & \\
\hline & \multicolumn{6}{|c|}{ HO: the absence of second-order autocorrelation } & \multicolumn{3}{|c|}{$0.8 \%$} \\
\hline & \multicolumn{6}{|c|}{ Hansen test } & \multicolumn{3}{|c|}{0.310} \\
\hline
\end{tabular}

Source: survey data.

Notice that in the second column of each of Tables 3-6, [A], the values of the estimated coefficients by the ordinary east squares for $\mathrm{EQI}_{\mathrm{t}-1}$ are, in fact, larger than the estimated values in column [B] for this same variable by the method of fixed-effects panel data. Therefore, if the instruments used are adequate, the value of the coefficient of this variable estimated by GMM should be between the limits of the estimated coefficients for the previous methods. That is precisely what occurs: the values obtained by this method for this variable in column [C] show that this characteristic is satisfied, thereby indicating that bias caused by the presence of endogenous variables on the right side of the regression and unobservable effects were corrected by the GMM.

Thus, among the models presented in Tables 3-6, this study opted for the method in column [C] of each table. The system GMM tests conducted show that the statistical properties of the models are acceptable. The Hansen test, which tests whether the instruments used and the additional tools required by the system GMM are valid, is satisfied for the four estimated models, as Tables 3-6 show. 
Table 4 - Results of estimates of ordinary least squares models, fixed effects, and generalized least squares for the urban non-agricultural labor market

\begin{tabular}{|c|c|c|c|c|c|c|c|c|c|}
\hline \multirow[t]{2}{*}{ Variables } & \multicolumn{3}{|c|}{$\begin{array}{l}\text { Ordinary least squares } \\
{[\mathrm{A}]}\end{array}$} & \multicolumn{3}{|c|}{$\begin{array}{l}\text { Fixed-effects model } \\
{[B]}\end{array}$} & \multicolumn{3}{|c|}{$\begin{array}{l}\text { Generalized least squares } \\
\text { [C] }\end{array}$} \\
\hline & Coef. & Stat. (t) & $p$-value & Coef. & Stat. (t) & $p$-value & Coef. & Stat. (t) & p-value \\
\hline$\overline{E . Q}$ Q. $I_{t-1}$ & 0.436 & 7.020 & 0.000 & -0.101 & -1.130 & 0.273 & 0.609 & 4.940 & 0.000 \\
\hline Agri. value added & 0.015 & 2.750 & 0.007 & -0.047 & -3.130 & 0.005 & 0.011 & 1.540 & 0.139 \\
\hline Non-agri. value added & -0.007 & -1.500 & 0.135 & 0.101 & 1.140 & 0.266 & -0.006 & -1.070 & 0.296 \\
\hline Average income & 0.205 & 6.420 & 0.000 & 0.797 & 7.900 & 0.000 & 0.145 & 3.160 & 0.005 \\
\hline Gini index & -0.053 & -0.680 & 0.498 & -0.167 & -1.380 & 0.183 & -0.051 & -0.340 & 0.738 \\
\hline Schooling & 1.649 & 7.740 & 0.000 & 0.445 & 1.630 & 0.118 & 1.191 & 3.370 & 0.003 \\
\hline Constant & -5.420 & -8.990 & 0.000 & -7.745 & -11.000 & 0.000 & -3.862 & -3.460 & 0.002 \\
\hline \multirow{9}{*}{ Statistical tests } & \multicolumn{3}{|c|}{$F(6,182)=576.65$} & \multicolumn{3}{|c|}{$F(6,20)=714.39$} & \multicolumn{3}{|c|}{$F(6,20)=680.36$} \\
\hline & \multicolumn{3}{|c|}{ Prob $>F=0.0000$} & \multirow{2}{*}{\multicolumn{3}{|c|}{ Prob $>F=0.0000$}} & \multirow{2}{*}{\multicolumn{3}{|c|}{ Prob $>F=0.000$}} \\
\hline & \multicolumn{3}{|c|}{$R^{2}=0.9554$} & & & & & & \\
\hline & Number & of comme & nts $=189$ & \multicolumn{3}{|c|}{ Number of comments $=189$} & \multicolumn{3}{|c|}{ Number of comments $=189$} \\
\hline & & & & \multicolumn{3}{|c|}{ Number of groups $=21$} & \multicolumn{3}{|c|}{ Number of groups $=21$} \\
\hline & & & & & & & \multirow{2}{*}{\multicolumn{3}{|c|}{ Instruments = 19.4}} \\
\hline & \multicolumn{6}{|c|}{ HO: the absence of first-order autocorrelation } & & & \\
\hline & \multicolumn{6}{|c|}{$\mathrm{HO}$ : the absence of second-order autocorrelation } & \multirow{2}{*}{\multicolumn{3}{|c|}{$\begin{array}{l}0.517 \\
0152\end{array}$}} \\
\hline & \multicolumn{6}{|c|}{ Hansen test } & & & \\
\hline
\end{tabular}

Source: survey data.

Finally, this study includes the statistical tests of Arellano and Bond (1991) to evaluate the existence of first- and second-order autocorrelation. Note that the absence of second-order autocorrelation is essential to the consistency of the estimator of system GMM. The test confirms the existence of first-order autocorrelation, although it rejects the hypothesis of second-order autocorrelation in the four models presented, which is expected and as per the panel data literature.

Thus, the models qualify as acceptable. It is initially observed that the coefficients of the variables agricultural value added and non-agricultural value added are not statistically significant for the non-agricultural employment, whether urban or rural. This shows an important behavioral characteristic of the non-agricultural labor market, since economic growth does not cause structural changes in the labor market for those groups. The increase in the number of employees does not imply increased quality of occupations because the quality of occupations of these new workers is, on average, similar to the quality of employment of those already employed, not by changing the structure of sophistication of work for these groups. This reinforces that by itself, the non-agricultural labor market induced by economic growth does not guarantee that existing and new employment relationships are modified. Thus, economic growth only extends the current forms of recruitment of workers to the new jobs. Therefore, their impacts in terms of improvement of working relations is practically null. 
Table $\mathbf{5}$ - Results of estimates of ordinary least squares models, fixed effects, and generalized least squares to the rural non-agricultural labor market

\begin{tabular}{|c|c|c|c|c|c|c|c|c|c|}
\hline \multirow[t]{2}{*}{ Variables } & \multicolumn{3}{|c|}{$\begin{array}{l}\text { Ordinary least squares } \\
{[\mathrm{A}]}\end{array}$} & \multicolumn{3}{|c|}{$\begin{array}{l}\text { Fixed-effects model } \\
{[\text { [B] }}\end{array}$} & \multicolumn{3}{|c|}{\begin{tabular}{|} 
Generalized least squares \\
{$[\mathrm{C}]$}
\end{tabular}} \\
\hline & Coef. & Stat. (t) & p-value & Coef. & Stat. (t) & $p$-value & Coef. & Stat. (t) & p-value \\
\hline$\overline{E . Q}$ Q. I. & 0.169 & 2.890 & 0.004 & 0.110 & 2.340 & 0.030 & 0.135 & 3.540 & 0.002 \\
\hline Agri. value added & 0.003 & 0.320 & 0.747 & 0.047 & 1.520 & 0.145 & -0.001 & -0.170 & 0.869 \\
\hline Non-agri. value added & -0.001 & -0.110 & 0.916 & -0.237 & -2.750 & 0.012 & 0.000 & 0.020 & 0.981 \\
\hline Average income & 0.501 & 14.260 & 0.000 & 1.003 & 15.110 & 0.000 & 0.525 & 32.970 & 0.000 \\
\hline Gini index & -0.309 & -2.560 & 0.011 & -0.142 & -0.730 & 0.477 & -0.330 & -2.460 & 0.023 \\
\hline Schooling & 0.507 & 5.420 & 0.000 & 0.011 & 0.050 & 0.959 & 0.508 & 6.330 & 0.000 \\
\hline Constant & -4.827 & -12.940 & 0.000 & -4.732 & -9.410 & 0.000 & -4.999 & -18.740 & 0.000 \\
\hline \multirow{9}{*}{ Statistical tests } & \multicolumn{3}{|c|}{$F(6,182)=351.09$} & \multicolumn{3}{|c|}{$F(6,20)=323.36$} & \multicolumn{3}{|c|}{$F(6,20)=2760.56$} \\
\hline & \multicolumn{3}{|c|}{ Prob $>F=0.000$} & \multirow{2}{*}{\multicolumn{3}{|c|}{ Prob $>F=0.000$}} & \multirow{2}{*}{\multicolumn{3}{|c|}{ Prob $>F=0.000$}} \\
\hline & \multicolumn{3}{|c|}{$R^{2}=0.9293$} & & & & & & \\
\hline & Number & of commen & ths $=189$ & \multirow{2}{*}{\multicolumn{3}{|c|}{\begin{tabular}{|l} 
Number of comments $=189$ \\
Number of groups $=21$
\end{tabular}}} & \multirow{2}{*}{\multicolumn{3}{|c|}{\begin{tabular}{|l|} 
Number of comments $=189$ \\
Number of groups $=21$
\end{tabular}}} \\
\hline & & & & & & & & & \\
\hline & & & & \multicolumn{3}{|c|}{ Number of groups $=21$} & \multicolumn{3}{|c|}{ Instruments $=19.4$} \\
\hline & \multicolumn{6}{|c|}{ HO: the absence of first-order autocorrelation } & \multicolumn{3}{|c|}{0.004} \\
\hline & \multicolumn{6}{|c|}{ HO: the absence of second-order autocorrelation } & \multicolumn{3}{|c|}{0.884} \\
\hline & \multicolumn{6}{|c|}{ Hansen test } & \multicolumn{3}{|c|}{0.123} \\
\hline
\end{tabular}

Source: survey data.

However, considering the levels of significance of these variables for both rural and urban agricultural workers (Tables 3 and 5), note that they are statistically significant at the level of $1 \%$. This shows that agricultural employment responds quite differently to economic growth compared to non-agricultural employment. Thus, economic growth affects the agricultural job market, because of an increase in activity, whether agricultural or non-agricultural, but in a different way. The negative sign result about the agricultural value added indicates that the growth in agricultural activities has an inverse relationship to the quality of employment in the two groups. This is because labor relations in agriculture are largely more precarious that in other sectors. Thus, as this system develops, it absorbs a portion of workers for activity with lower formalization and income, bigger workload, and higher probability of child labor occurring (characteristics of agricultural employment), which, on average, tends to reduce the quality index of employment for that group.

Different types of behavior are found for the variable value added agricultural have a positive sign and are not significant - showing that agricultural employment depends more strongly on the dynamics of non-agricultural activities, enhancing urbanization beyond the limits of the cities. Thus, the quality of the job increases owing to the economic growth of non-agricultural activities. Notice that the forms of hiring of labor for these activities are much more formalized, as better yields, lower workload, and lower incidence of child labor, as described by Schneider (2005). With that, as the work trend develops, labor influences agricultural work through the process of sectoral migration, since agricultural workers are worse off in this market and are seeking to engage in activities in other sectors in which quality levels are better, thereby improving the average level of quality in the market of agricultural work. 
Table 6 - Results of estimates of ordinary least squares models, fixed effects, and generalized least squares to the rural agricultural labor market

\begin{tabular}{|c|c|c|c|c|c|c|c|c|c|}
\hline \multirow[t]{2}{*}{ Variables } & \multicolumn{3}{|c|}{$\begin{array}{l}\text { Ordinary least squares } \\
\text { [A] }\end{array}$} & \multicolumn{3}{|c|}{$\begin{array}{l}\text { Fixed-effects Model } \\
{[B]}\end{array}$} & \multicolumn{3}{|c|}{$\begin{array}{c}\text { Generalized least squares } \\
{[C]}\end{array}$} \\
\hline & Coef. & Stat. $(t)$ & p-value & Coef. & Stat. $(t)$ & p-value & Coef. & Stat. (t) & p-value \\
\hline E. Q. $I_{t-1}$ & 0.320 & 3.990 & 0.000 & 0.230 & 3.700 & 0.001 & 0.295 & 3.090 & 0.006 \\
\hline Agri. value added & -0.005 & -0.360 & 0.719 & -0.004 & -0.120 & 0.902 & -0.193 & -4.260 & 0.000 \\
\hline Non-agri. value added & 0.011 & 1.140 & 0.256 & -0.141 & -1.250 & 0.225 & 0.092 & 3.740 & 0.001 \\
\hline Average income & 0.470 & 7.140 & 0.000 & 1.171 & 15.600 & 0.000 & 0.498 & 9.090 & 0.000 \\
\hline Gini index & 0.081 & 0.500 & 0.614 & 0.231 & 1.710 & 0.102 & -0.902 & -2.120 & 0.047 \\
\hline Schooling & 0.538 & 4.400 & 0.000 & -0.534 & -1.990 & 0.061 & 0.301 & 2.150 & 0.044 \\
\hline Constant & -4.360 & -7.530 & 0.000 & -4.849 & -7.080 & 0.000 & -4.144 & -6.100 & 0.000 \\
\hline \multirow{9}{*}{ Statistical tests } & \multicolumn{3}{|c|}{$F(6,182)=493.20$} & \multicolumn{3}{|c|}{$F(6,20)=319.30$} & \multicolumn{3}{|c|}{$F(6,20)=1712.22$} \\
\hline & \multicolumn{3}{|c|}{ Prob $>F=0.000$} & \multirow{2}{*}{\multicolumn{3}{|c|}{ Prob $>F=0.000$}} & \multirow{2}{*}{\multicolumn{3}{|c|}{ Prob $>F=0.000$}} \\
\hline & \multicolumn{3}{|c|}{$R^{2}=0.9293$} & & & & & & \\
\hline & Number & of comme & nts $=189$ & \multicolumn{3}{|c|}{ Number of comments $=189$} & \multicolumn{3}{|c|}{ Number of comments $=189$} \\
\hline & & & & \multicolumn{3}{|c|}{ Number of groups $=21$} & \multicolumn{3}{|c|}{ Number of groups $=21$} \\
\hline & & & & & & & & & \\
\hline & \multicolumn{6}{|c|}{ HO: the absence of first-order autocorrelation } & \multicolumn{3}{|c|}{0.048} \\
\hline & \multicolumn{6}{|c|}{ HO: the absence of second-order autocorrelation } & \multicolumn{3}{|c|}{0.170} \\
\hline & \multicolumn{6}{|c|}{ Hansen test } & & 0.245 & \\
\hline
\end{tabular}

Source: survey data.

In the case of variable income, the estimated coefficient is statistically significant at a significance level of $1 \%$ and with a positive sign, as expected, for the four equations examined. Thus, the increments in the income of worker have important impacts on the quality of employment. This indicates that a policy of valorization of real income from work can be deeply important to improve the quality standards of occupations and, above all, the profile of workers. From this perspective, the increase in income is conditioned for jobs with better ways of recruiting labor. In addition, an increase in income implies improvement of other conditions as formalization, contribution to provident institutions, and increasing the quality of the occupation. Thus, an increase in income leads to a process of competition in the labor market. Thus, those who offer employment are encouraged to improve their hiring models to obtain workers they want and the workers feel less encouraged to remain in precarious jobs - of inferior quality - with lower income levels.

With regard to elasticity relations that it can be establish, an increase of $1 \%$ on income from work has a greater impact on the quality of non-agricultural rural employment $(0.53 \%)$ followed by the rural agricultural employment $(0.48 \%)$. Notice that the elasticity employment income quality is less than the unit and therefore, is more inelastic. Nevertheless, the idea of income recovery from work can also contribute to the reduction of differences between the urban and rural labor markets, since the effects of income-level elevations at first are smaller.

In the case of the Gini index, which measures the level of concentration of income, it is statistically significant for the urban agricultural employment, non-agricultural rural, and agricultural rural. In this case, the structure of income concentration has an impact on the level of quality of work in these segments of the labor market. The reduction of the Gini index implies that the level of income of the poorest workers converges to a higher income level with reflections 
in terms of job quality, since the variable is inversely proportional to the Gini EQI in all models introduced. Only in the case of urban non-farm employment does the Gini index not significantly influence the quality of employment. Thus, non-agricultural labor relations are maintained with a dynamic of their own, regardless of the level of income concentration.

Finally, it is noteworthy that the average school enrollment rate is significant at a level of $1 \%$ and with a positive sign, according to your expected behavior within these models for the four equations. From this perspective, the level of schooling of the worker positively influences the quality of employment by increasing the possibility of the employee to obtain more sophisticated jobs with increases in their levels of education. This is consistent with the literature that deals the education as an inducer of work improvement.

From the perspective of studies of elasticities, a $1 \%$ increase in the average education level of workers has a more than proportional impact on the level of quality of the work, ceteris paribus. This shows that investments in education and training are very efficient in terms of performance and improvement of the quality of service of workers due to the elastic behavior of the quality of employment in relation to education.

In the case of the variable quality of employment behind in a period, the coefficient is positive and significant at a significance level of $1 \%$ in the four models. Thus, the quality of employment tends to persist from one year to the next, since $1 \%$ increases in quality of employment passed, ceteris paribus, lead to an increase of $0.31 \%$ in urban agricultural jobs, a $0.61 \%$ increase in urban non-farm employment, a $0.13 \%$ increase in non-agricultural rural employment, and finally, a $0.29 \%$ increase in agricultural employment. Thus, the quality of past jobs tends to persist more strongly in non-farm employment. This is because this labor market, in addition to being more sophisticated that the others, presents a higher level of formalization and incidence of labor laws, as described by Tafner (2006). The logic consists of a worker's behavior and the dynamics of the labor market.

Generally, workers have to change their workplace if the conditions offered in future jobs are better than those in current jobs. It is argued that the job market presents some resistance in terms of reducing labor achievements. Thus, generally, rights acquired are not lost over time. This behavior is reflected in the quality of employment in that it creates some resistance when it comes to best conditions of work already acquired. This causes the persistence of quality of employment and its influence on present employment.

\section{FINAL CONSIDERATIONS}

It is generally known that the recent transformation of the countryside panorama has had important influences on labor relations. However, it noted be in this research that these changes go far beyond the new dynamics of production of the universe. The rural employment behavior obeys a number of constraints that go far beyond those in the countryside. In addition, an urban dynamic is important to evaluate the accuracy of the trajectory of relations of rural work.

The job quality index proposed in this research showed deep heterogeneity in labor relations needs when considering the economic activities needed in the areas studied. Generally, agricultural workers face more precarious working conditions than non-agricultural workers do. The level of formality of farm work is an example of this, being far less common for workers in this group than for the other groups surveyed. On the asymmetry in the labor market, record 
that the differences between urban and rural employment, because the rural universe persists as a more precarious environment compared to the urban environment, although the differences decrease with time (ESCHER et al., 2014).

Finally, it observe be from the analyses of the models that, in general, economic growth reflects more heavily on agricultural employment than non-agricultural employment. The dynamics of non-agricultural activities positively influence the quality level of agricultural employment to extend to these workers opportunities for better jobs than those in agriculture. With regard to the pace of agricultural activity, the ratio is reversed, and agricultural employment is generally a form of more precarious employment, depriving employees from the possibilities of achieving better working conditions.

In non-farm employment, this study finds a different dynamic, recent economic growth extended the same forms of contracting already checked, and thus, had no major impacts in terms of structural changes on the labor markets surveyed. An important caveat must be made here: the long-term behavior of the labor market can present different dynamics to those verified so far, because as the economy approaches full employment induced by economic growth, the extension of these forms of employment for unemployed workers becomes increasingly difficult. Thus, as economic growth takes place, the same result achieved in the long run is expected to cause changes in the structure of the labor market. Thus, the data reflect the fact that labor relations are sensitive to economic growth stages at the rate of economic growth itself (BALSADI, 2007).

In addition, the survey showed that the growth of income from work and the average level of education of workers are important instruments not only for expanding the quality of employment level, but also as a strategy for overcoming dilemmas of the markets surveyed, as is the case with the heterogeneity observed between the groups.

\section{REFERENCES}

AHN, S. C.; SCHMIDT, P. Efficient estimation of models for dynamic panel data. Journal of Econometrics, v. 68, n. 1, p. 5-27, July 1995.

ALVES, C. L. B.; PAULO, E. M. Mercado de trabalho rural cearense: evolução recente a partir dos dados da PNAD. Revista da ABET, João Pessoa, PB, v. 11, n. 2, p. 47-61, jul./dez. 2012.

ARAÚJO, J. A. Pobreza, desigualdade e crescimento econômico: três ensaios em modelos de painel dinâmico. 2009. Thesis (PhD in Economics)- Federal University of Ceará (UFC), Fortaleza, 2009.

ARELLANO, M.; BOND, S. Some tests of specification for panel data: Monte Carlo evidence and an application to employment equations. The Review of Economic Studies, v. 58, n. 2, p. 277-97, Apr. 1991.

ARELLANO, M.; BOVER, O. Another look at the instrumental variable estimation of error components model. Journal of Econometrics, v. 68, n. 1, p. 29-52, July 1995.

BALSADI, O. V. Qualidade do emprego na agricultura brasileira no período 2001-2004 e suas diferenciações por culturas. Revista de Economia e Sociologia Rural, Brasília, DF, v. 45, n. 2, p. 409-44, abr./jun. 2007.

BALSADI, O. V.; DA SILVA, J. F. G. A polarização da qualidade do emprego na agricultura brasileira no período 1992-2004. Economia e Sociedade, Campinas, SP, v. 17, n. 3, p. 493-524, dez. 2008.

BALTAGI, B. H. Econometric analysis of panel data. 3rd ed. New Delh: John Wiley \& Sons, 2005.

BLUNDELL, R.; BOND, S. Initial conditions and moment restrictions in dynamic panel data models. Journal of Econometrics, v. 87, n. 1, p. 115-43, Nov. 1998.

BOND, S.; HOEFFLER, A.; TEMPLE, J. GMM Estimation of Empirical Growth Models. CEPR Discussion Papers 3048, 2001. 
DA SILVA, J. G. A nova dinâmica da agricultura brasileira. 2. ed. Campinas, SP: UNICAMP, 1998.

ESCHER, F. et al. Caracterização da pluriatividade e dos plurirrendimentos da agricultura brasileira a partir do Censo Agropecuário 2006. Revista de Economia e Sociologia Rural, Brasília, DF, v. 52, n. 4, p. 643-67, out./dez. 2014.

NASCIMENTO, C. A.; BRENDA SOUTO, J. G.; OLIVEIRA, R. B.; MENDES, S. R. A qualidade do emprego rural no Estado de Minas Gerais na região Sudeste nos últimos anos, 2002 e 2004. In: Congresso da Sociedade Brasileira de Economia Administração e Sociologia Rural, 45. Anais... Londrina: SOBER, 2007.

PAULO, E. M. Determinações do grau de qualidade do emprego: um ensaio em modelo de painel dinâmico. 2015. Masters dissertation (MD in Economics) - Federal University of Ceará (UFC), Fortaleza, 2015.

SCHNEIDER, S. As novas formas sociais do trabalho no meio rural: a pluriatividade e as atividades rurais não-agrícolas. Revista Redes, Santa Cruz do Sul, RS, v. 9, n. 3, p. 75-109, 2005.

TAFNER, P. (Ed.). Brasil: o estado de uma nação. 1. ed. Rio de Janeiro: IPEA, 2006.

WINDMEIJER, F. A finite sample correction for the variance of linear efficient two-step GMM estimators. Journal of Econometrics, v. 126, n. 1, p. 25-51, may 2005.

\section{Sobre os autores:}

Evânio Mascarenhas Paulo: PhD. Students in Economics at Pontifical Catholic University of Rio Grande do Sul and Master in Rural Economics at Federal University of Ceará. E-mail: evanio.paulo@acad.pucrs.br.

Francisco José Silva Tabosa: PhD. in Economics at Federal University of Ceará and Master in Rural Economics at Federal University of Ceará and Professor of Department of Rural Economics at University of Ceará. E-mail: franze@caen.ufcc.br. 
